\title{
The Effect of Transformational Leadership and Reward Towards Job Performance of Counter Transnational Organized Crime Task Force of Bali Region Police Through Felt Accountability and Job Satisfaction as Mediating Variables
}

\author{
$1^{\text {st }}$ B Dananjaya \\ Faculty of Administrative Science \\ Universitas Indonesia \\ Jakarta, Indonesia \\ bangkitdananjaya@gmail.com
}

\author{
$2^{\text {nd }}$ F D Saragih \\ Faculty of Administrative Science \\ Universitas Indonesia \\ Jakarta, Indonesia
}

\author{
$3^{\text {rd }}$ B Y Nugroho \\ Faculty of Administrative Science \\ Universitas Indonesia \\ Jakarta, Indonesia
}

\begin{abstract}
The objective of this research is to analyse the transformational leadership impact and reward impact toward job performance of Counter Transnational Organized Crime Task Force Bali Region Police through felt accountability and job satisfaction as mediator variable. This is a quantitative research using survey method to 113 personnel of CTOC Task Force Bali Regional Police (CTOC Task Force Polda Bali). The data are collected through descriptive-statistics analysis and SEM-PLS. The result shows that there is a positive impact of transformational leadership to felt accountability with $t$-statistics value of 4.237 > 1.96. Transformational leadership has positive impact towards job satisfaction with t-statistics value of 6.551 > 1.96. Reward has positive impact towards felt accountability with $t$-statistics value of $3.309>1.96$. Reward has positive impact towards job satisfaction with t-statistics value of 4.026 > 1.96. Felt accountability has positive impact towards job performance with $t$-statistics value of 2.931 > 1.96. Job satisfaction has positive impact towards job performance with $t$-statistics value of $7.388>1.96$.
\end{abstract}

Keywords-Transformational Leadership, Reward, Felt Accountability, Job Satisfaction, Job Performance, Counter Transnational Organized Crime Task Force, Bali Region Police

\section{INTRODUCTION}

Job performance illustrates the accomplishments of activity, program, or policy implementation in actualizing an organization vision and mission [18]. [4] explained that job performance is not only based on what people or employee had obtained, but also how they obtain it. The Counter Transnational Organized Crime Task Force (Satgas CTOC) is a task force made by Chief of Bali Regional Police in the beginning of 2017 to help Bali
Region Police to counter crime in Bali, especially in 5 fields which are terrorism, narcotics, corruption and extortion, cybercrime, and other prominent crimes. CTOC Task Force's job performance is shown by revealing numbers of cases done by CTOC according to its task and function. In hindsight, CTOC Task Force has revealed number of cases in line with its main job, for example: narcotics, extortion and corruption, and cybercrime. In general, CTOC's Task Force job performance is excellent due to revealing numbers of cases done in accordance with its main target when established.

This research is conducted to test factors affecting CTOC Task Force's job performance. Job performance is affected by some factors. One of them is transformational leadership. [5] explained that a transformational leader motivates people to do more than what they meant, or even what they think they could. This kind of leadership is shown by Bali Chief of Region Police by initiating CTOC Task Force. In former research, transformational leadership has a direct positive and significant impact on employee's job performance, as written by [2].

Another factor which affect employee's job performance is the reward. Reward is tangible or intangible thong that an organization provides to its employees either intentionally or unintentionally in exchange for the employee's potential or actual work contribution, and to which employees as individuals attach a positive value as a satisfier or certain self-defined needs [22]. In former research, [16] found that reward system has several positive and significant impacts on employee's job performance.

In this research, two mediator variables of felt accountability and job satisfaction will be placed between 
the dependent or endogen variable (job performance) and the independent or exogen variable including transformational leadership and reward. Felt accountability is accountability handled by an individual or a social obligation that emerges when someone is bound to an organization [14]. Felt accountability or accountability perceives humans' decision or action expectations that will be evaluated by salient audiences, therefore, these rewards or sanctions are believed to be contingent based on this expected evaluation [13]. As per to [8] it is found that employees who work in machinestructured corporates often has lower felt accountability compared to employees who work in adhocracy-based corporates. Indonesian National Police organization (Polri) is an example of one mechanical and formal organization which has a clear hierarchy depending on rank and position. In this research, CTOC Task Force, which all personnel are active Indonesian police members, shows great job performance.

In this research, job satisfaction is considered as the second mediator variable. [23] wrote that job satisfaction is an attitudinal construct reflecting one's evaluation of one's job. Job satisfaction variable will be tested in its impact on their job performance. [9] on their research showed that job satisfaction has positive and significant impacts on job performance.

Based on the descriptions above, the main problems asked in this research are: 1) How does transformational leadership affect felt accountability? 2) How does transformational leadership affect job satisfaction? 3) How does reward affect felt accountability? 4) How does reward affect job satisfaction? 5) How does felt accountability affect job performance? 6) How does job satisfaction affect job performance?

\section{LITERATURE REVIEW}

[5] explained that a transformational leader motivates people to do more than what they meant, or even what they think they could. This kind of leadership sets more challenging hopes and it will resulting in higher job performance and achievements. There are 4 dimensions of transformational leadership according to [7], which are idealized influence, inspirational motivation, intellectual stimulation, and individualized consideration.

[22] explained that a reward is anything tangible or intangible provided by organization intentionally or unintentionally to its employees. He divided reward into two parts which are intrinsic and extrinsic rewards. Intrinsic reward came from the core of the work itself, including passion and challenge it gave, variation of tasks and autonomy, feedback level, and means that associated with it. Extrinsic reward came from such factors that associated with the work contexts. Extrinsic reward are divided into three types which are financial, development, and social reward.

Felt accountability is accountability felt by an individual or a social obligation that emerges when someone is bound to an organization [14]. [14] mentioned 8 indicators to measure felt accountability which are 1) Being responsible of own action in the workplace, 2) Lead management to ask for the responsibility of all decisions from subordinates 3) If anything did not go well, the employee will hear it from the top management, 4) Workgroup success is dependent on success and failure of each individual, 5) Employees are expected to be able to explain why they do certain things at work, 6) In a larger scheme, the effort of each employee matters, 7) Work of employees in the workplace is dependent to their own success or failure, and 8) Co-worker, subordinate, and leader meticulously observe employee's effort in the workplace.

Job satisfaction is someone's opinion on how good their work is according to expectation [17]. There are five job satisfaction dimensions according to [17] which are the work itself, salary, promotion opportunities, supervision, and co-workers.

[1] wrote two dimensions of job performance including task performance and contextual performance. Task performance is related to each individual's skill and abilities. On the other hand, contextual performance is defined as employeers' behavior that contributed to the effectivity of organization in a way to provide good environment where task performance could be demonstrated well.

Therefore, the hypotheses in this research are:

H1: Transformational leadership has positive impact on felt accountability.

H2: Transformational leadership has positive impact on job satisfaction.

H3: Reward has positive impact on felt accountability.

H4: Reward has positive impact on job satisfaction.

H5: Felt accountability has positive impact on job performance.

H6: Job satisfaction has positive impact on job performance.

\section{RESEARCH METHOD}

The research method used is the quantitative method that is explanatory-based. On this research, all population mentioned are containing all personnel of CTOC Task Force of 113 people in total. The technique to define these samples is total sampling. Total sampling is taking sample in an identical number from the total population [3]. The sample of all CTOC Task Force contains 113 personnel. Total sample for SEM research is minimum of 100 samples [11]. This research utilizes two data resources which are primary and secondary data. Primary data on this research is obtained by questionnaire to CTOC Task Force personnels. Secondary data on this research are gained from journals, articles, and books supporting the research and data on CTOC Task Force personnel.

In this research, the method to gain data is through questionnaire method. Questionnaire method is statements or questions used to gain information from respondents [3]. The scale used to measure variable of each utilizes Likert scale, in the form of agree-disagree scale with interval between 1 and 5 [11]. There are 5 scale used including 5: SA (Strongly Agree), 4: A (Agree), 3: N (Neutral), 2: D (Disagree) and 1: SD (Strongly Disagree). Technique to analyze these data is divided into two technique which are descriptive-analysis and interferential 
analysis by utilizing analytic tool of Partial Least SquareStructural Equation Modeling (PLS-SEM).

\section{RESULT}

\section{A. Respondent Profiles}

CTOC Task Force consisted of 7 teams, insisting of 34 people in surveillance team, 5 people in direction finder and digital forensic team, 15 people in analysis team, 12 people in interrogator team, 13 people in enforcers team, 29 people in patrol team, and 5 people in investigator team. The average of CTOC Task Force employees' ages is between 22 to 30 years old ( 83 people), with majority of respondents are male (103 people or $91,20 \%)$. By rank, the data generated is mostly from the police brigadier $1^{\text {st }}$ class (Briptu) consisting of 39 people or $34,40 \%$, with 46 people's serving period between 1 to 5 years. Majority of respondents, 63 people or $55,80 \%$, graduated from high school.

B. Model Measurement Analysis (Outer Model) Using Partial Least Square-Structural Equation Model (PLSSEM)

In this research, transformational leadership variable consists of 10 indicators including TL1 to TL10 and reward variable which consists of 8 indicators, R1 to R8. Furthermore, felt accountability variable is consisted of 8 indicators which is FA1 to FA8, and job satisfaction variable consisting of 12 indicators which is JS1 to JS12, and last, job performance variable consists of 9 indicators: JP1 to JP9.

Convergent Validity Test

In this research, the writers utilize loading factor as much as 0.50 . If loading factor $\geq 0.50$ then convergent validity is fulfilled, and if loading factor $<0.50$ then construct must be dropped from the analysis. K5 and K6 indicators on this test has loading factors, each valued at 0.454 and 0.330 , thus both are eliminated from further test.

Discriminant Validity Test

As per to this test, the indicators JS4, JS5, JS6 and JS8 does not meet the criteria since they have lower cross loading value than other indicators, thus these four are eliminated. Other than that, Discriminant Validity could be rated by considering Average Variance Extracted (AVE), recommended AVE for each construct larger than 0.5. [12].

TABLE I AVERAGE VARIANCE EXTRACTED (AVE)
\begin{tabular}{|c|c|}
\hline Construct & AVE \\
\hline JP & 0.772 \\
\hline FA & 0.541 \\
\hline JS & 0.675 \\
\hline TL & 0.832 \\
\hline R & 0.580 \\
\hline
\end{tabular}

According to the table above, the result of AVE $>0.5$, therefore, it that can be concluded that all variable in the model are fit to discriminant validity criteria. According

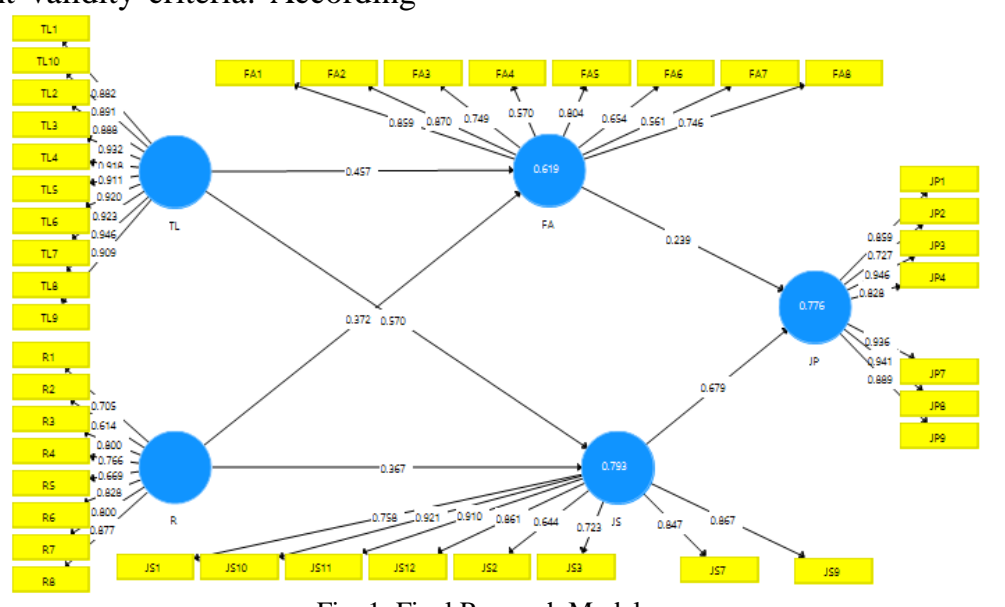

Fig. 1. Final Research Model

\section{Composite Reliability Test}

The third step is testing the composite reliability to calculate the variables' reliability. Variable with good to convergent validity and discriminant validity test, final model gained is as illustrated below:

TABLE II. COMPOSITE RELIABILITY VALUE

\begin{tabular}{|c|c|c|}
\hline Variabel & Composite Reliability & Result \\
\hline JP & 0.959 & Accomplished \\
\hline FA & 0.902 & Accomplished \\
\hline JS & 0.943 & Accomplished \\
\hline TL & 0.980 & Accomplished \\
\hline R & 0.916 & Accomplished \\
\hline
\end{tabular}


According to table above, all constructs has fulfilled reliable criteria. This is shown by construct composite reliability value more than 0,60 .

C. Structural Model Analysis (Inner Model) Using Partial Least Square-Structural Equation Model (PLSSEM)

Inner model or structural model test is conducted to see relation between variable, significance value and R- square from research model. To estimate the model in PLS method, the first step is observing R-Square to each latent dependent variable [12].

$\underline{R \text {-square Test }}$

Using SmartPLS to conduct $\mathrm{R}^{2}$ test from data extraction output. The result is gained by seeing value on R Square table as shown below:

TABLE $3 . \mathrm{R}^{2}$ TEST RESULT

\begin{tabular}{|c|c|c|}
\hline Construct & R Square & R Square adjusted \\
\hline FA & 0.619 & 0.612 \\
\hline JS & 0.793 & 0.789 \\
\hline JP & 0.776 & 0.772 \\
\hline
\end{tabular}

$\mathrm{R}_{\mathrm{FA}}{ }^{2}$ value 0.619 for felt accountability (FA) shows the impact of transformational leadership (TL) and reward (R) variables collectively to FA by $61.9 \%$. The rest of it, $38.1 \%$, is explained by other variable outside TL and R. The same method can be applied to two other endogen variables. $\mathrm{R}_{\mathrm{JS}}{ }^{2}$ value for job satisfaction (JS) is $79.3 \%$, showed that JS is impacted by TL and R together with $79.3 \%$. The rest, $20.7 \%$ is affected by other variables which are not mentioned in this research. Other endogen variable, job performance (JP), has $\mathrm{R}_{\mathrm{JP}}^{2}$ value of 0.776 . This means job performance (JP) is impacted by FA and JS together with $77.6 \%$. The rest, $22.4 \%$, is affected by other variable not mentioned in this research.

Hypotheses Test

1) Relation between TL $\rightarrow$ FA is significant with Tstatistic of $4.237>1.96$. Original sample value is 0.455 , showing positive direction between TL $\rightarrow$ FA.

2) Relation between TL $\rightarrow$ JS is significant with Tstatistic of $6.551>1.96$. Original sample value is 0.455 , showing positive direction between TL $\rightarrow$ JS.

3) Relation between $\mathrm{R} \rightarrow \mathrm{FA}$ is significant with $\mathrm{T}$ statistic of $3.309>1.96$. Original sample value is 0.373 , showing positive direction between $\mathrm{R} \rightarrow$ FA.

4) Relation between R $\rightarrow$ JS is significant with Tstatistic of $4.026>1.96$. Original sample value is 0.275 , showing positive direction between $\mathrm{R} \rightarrow \mathrm{JS}$.

5) Relation between FA $\rightarrow$ JP is significant with Tstatistic of $2.931>1.96$. Original sample value is 0.236 , showing positive direction between FA $\rightarrow \mathrm{JP}$.

6) Relation between JS $\rightarrow$ JP is significant with Tstatistic of $7.388>1.96$. Original sample value is 0.681 , showing positive direction between JS $\rightarrow$ JP.

\section{DISCUSSION}

In this research, the transformational leadership variable shows positive impacts on felt accountability. This result is in accordance with [14] which found the positive correlation between transformational leadership towards felt accountability. This can be concluded that the better transformational leadership put in CTOC Task Force, the more felt accountability gained in the force.

Transformational leadership variable has a positive impact towards job satisfaction. This result is in accordance to [19] and [20], which stated that transformational leadership has positive impact on job satisfaction. Job satisfaction can be gained from various sources, including transformational leadership shaped by the leader. Satisfaction will remove any disturbances in an employee's job performance in an organization. Job satisfaction will support good emotional atmosphere in an individual. Increasing job satisfaction in an individual will result in a good output for organization. Job satisfaction will help to increase employees job performance, either in qualitative or quantitative value, where those satisfied employees will get easily motivated and they will have high interest in their jobdesks.

Reward variable has positive impact on felt accountability. This result is in line with [21], who discovered the relationship between reward and felt accountability. If the reward given by organization is appropriate with employee's job, the employee will feel more accountability, social responsibility, and bond with the organization. Reward is also part of compensation. Compensation can be simply described as anything employee had gained as the benefits towards their work [15].

Reward variable also has positive impact to job satisfaction. The better reward given by the corporation, the more job satisfaction level will increase. If reward gained by CTOC Task Force is appropriate to their expectation, it will affect to the raise of job satisfaction in CTOC Task Force personnels. This is in accordance with [10], who wrote the impact of reward on job satisfaction. Reward given by organization, intrinsic or extrinsic, can be used to motivate employees. Positive, interesting, fair, and appropriate awards to employees will increase their job satisfaction.

Felt accountability variable has a positive result to job performance. It can be concluded that the better felt accountability on CTOC Task Force, the more job performance will be increasing in the force. This is in accordance with [14], who found positive impact of felt accountability on job performance. [14], also wrote that felt accountability is employees' feeling who want to keep their position in one organization. Felt accountability is gained because an employee felt a social responsibility when they are bond to an organization [14].

Job satisfaction variable has positive impact on job performance in CTOC Task Force. This is in accordance with [24] who found that job satisfaction as a factor which affecting job performance. When job satisfaction is 
achieved, job performance will be high and vice versa [6]. CTOC Task Force personnel who gained job satisfaction will perform more on their job. Job satisfaction on the force will facilitate CTOC Task Force personnel to achieve organization goals, which will increase their job performance. This shown that the more job satisfaction gained by CTOC personnel, the more they will perform, and the end result will be better and vice versa. If CTOC personnel feel satisfied with their job, they will work more enthusiastically. This drive will support the organization's main goals. [24] wrote that job satisfaction has a role as job performance predictor. This is due to job satisfaction is moderately correlated to job performance. It can be concluded that the level of job satisfaction of CTOC Task Force personnels will impact job performance. If job satisfaction is gained, job performance of CTOC Task Force personnel will be higher, vice versa.

\section{CONCLUSION AND RECOMMENDATION}

\section{A. Conclusion}

- Transformational leadership has positive impact on felt accountability with t-statistic value of $4.237>1.96$

- Transformational leadership has positive impact on job satisfaction with t-statistic value of 6.551 $>1.96$.

- Reward has positive impact on felt accountability with t-statistic value of $3.309>1.96$

- Reward has positive impact on job satisfaction with t-statistic value of $4.026>1.96$.

- Felt accountability has positive impact on job performance with t-statistic value of $2.931>$ 1.96.

- Job satisfaction has positive impact on job performance with t-statistic value of 7.388 > 1.96.

\section{B. Recommendation}

Based on this research, the impact of felt accountability variable has the smallest statistical value to the job performance. Thus, to increase job performance especially in felt accountability of CTOC Task Force personnel, CTOC Task Force leader has to increase each personnels' responsibility, increase group work in CTOC Task Force, and increase the accuracy in each job done by team members and leaders.

\section{REFERENCES}

[1] Aguinis, H. 2013. Performance Management Third Edition. New Jersey: Pearson Education.

[2] Al-Amin, M. 2017. Transformational Leadership And Employee Performance Mediating Effect Of Employee Engagement. North South Business Review, Volume 7, Number 2, 28-40.

[3] Arikunto, S. 2010. Prosedur Penelitian Suatu Pendekatan Praktik. Jakarta: Rineka Cipta.

[4] Armstrong, M. 2006. Performance Management Key Strategies and Practical Guidelines. London and Philadelphia: Kogan Page.

[5] Avolio, B. J., \& Bass, B. M. 2002. Developing Potential Across A Full Range Of Leadership Cases on Transactional and Transformational Leadership. New Jersey: Lawrence Erlbaum Associates.

[6] Bakan, I., Buyukbese, T., Ersahan , B., \& Sezer, B. 2014. Effects of Job Satisfaction on Job Performance and
Occupational Commitment. International Journal of Management \& Information Technology Vol. 9, No. 1, 14721480.

[7] Bass, B. M., \& Avolio, B. J. 1994. Improving organizational effectiveness: through transformational leadership. London: Sage Publications.

[8] Dewi, R. C. \& Riantoputra, C. D. 2019. Felt accountability: the role of personality and organizational factors. Journal of Management Development Vol. 38 No. 4. 312-322.

[9] Eliyana, A., Ma'arif, S., \& Muzakki. 2019. Job Satisfaction and Organizational Commitment Effect in the Transformational Leadership towards Employee Performance. European Research on Management and Business Economics 25 (2019), 144-150.

[10] Emadzade, M. K. 2016. The Effect Of Rewards and Motivating on Mantaining and Keeping Human Resources Case Study in Amin Hospital (Isfahan) and Alassad Aljameie (Lattakia). Interdisciplinary journal of contemporary research in business, Vol. 3, No. 9.

[11] Ferdinand. 2006. Metode Penelitian Manajemen. Semarang: Universitas Diponegoro.

[12] Ghozali, Imam. 2011. SEM Metode Alternatif dengan Partial Least Square (PLS). $3^{\text {rd }}$ Edition. Semarang: Universitas Diponegoro

[13] Hall, A. T., \& Ferris, G. R. 2011. Accountability and Extra-Role Behavior. Employ Respons Right J 23.131-144.

[14] Hall, A. T., Zinco, R., Perryman, A. A., Ferris, G. R. 2009. Mediators in the Relationships Between Accountability and Job Performance and Satisfaction. Journal of Leadership \& Organizational Studies Volume 15 Number 4. 381-392.

[15] Handoko, T. H. 2012. Manajemen Personalia \& Sumberdaya Manusia. Yogyakarta: BPFE.

[16] Hasanudin, A. I., \& et al. 2018. Four Possible Rewards (or Punishments) for Innovation-Their Effect on The Employee. Problems and Perspective in Management, Volume 16, Issue 2, 232-240.

[17] Luthans, F. 2011. Organizational Behavior: An Evidence-Based Approach, Twelft Edition. Singapore: McGraw-Hill Education.

[18] Mahsun, M. 2006. Pengukuran Job performance Sektor Publik. Yogyakarta: BPFE Yogyakarta.

[19] Markos, S., \& Sridevi, M. S. 2010. Employee Engagement: The Key to Improving Performance. International Journal of Business and Management, 5 (12), 89-96.

[20] Nielsen, K., Yarker, J., Randall, R., \& Munir, F. 2009. The mediating effects of team and self-efficacy on the relationship between transformational leadership, and job and psychological well-being in healthcare professionals: A cross-sectional questionnaire survey. International Journal of Nursing Studies, 46, 1236-1244.

[21] Royle, T. 2017. The Mediating Effect of Felt Accountability on The Relationship Between Personality And Job Satisfaction. International Journal of Management and Marketing Research, Vol. 10, No. 1, 19-44.

[22] Shields, J. 2007. Managing Employee Performance and Reward Concepts, Practices, Strategies. Cambridge: Cambridge University Press.

[23] Wagner III, J. A., \& Hollendbeck, J. R. 1992. Management of Organizational Behaviour. New Jersey: Prentice Hall, Inc.

[24] Wibowo. 2015. Perilaku Dalam Organisasi. Jakarta: Rajawali Pers. 